\title{
Industrial Buildings and Their Role in the Transformation of a Regional Greek City: The Tobacco Warehouses of Agrinio
}

\author{
Dora Monioudi-Gavala \\ Department of Cultural Heritage Management and New Technologies, University of Patras, Patras, Greece \\ Email:dmoga@upatras.gr
}

Received 12 February 2016; accepted 11 April 2016; published 14 April 2016

Copyright (C) 2016 by author and Scientific Research Publishing Inc.

This work is licensed under the Creative Commons Attribution International License (CC BY).

http://creativecommons.org/licenses/by/4.0/

\section{(c) (i) Open Access}

\begin{abstract}
This paper presents the role of the tobacco warehouses in the urban transformation of the provincial Greek city of Agrinio. It covers the period from the establishment of the Greek state in 1830 to the end of the interwar period, with special focus on the 1920s and 1930s. The study of this particular city is done within the broader historical environment of the Greek state, in which urban planning and architecture are among the more general issues raised by the historical conditions. The new data brought to light by the study show the significance of the tobacco warehouses in shaping the city of Agrinio, as well as the influences from Central Europe on local industrial architecture during the interwar years.
\end{abstract}

\section{Keywords}

Tobacco, Warehouses, Architecture, Interwar, Greece, Agrinio

\section{Introduction}

Architecture is acknowledged to be one of the most characteristic creations of a society. Indeed, buildings are frequently used as emblems of a city and its inhabitants. Such is the case with the tobacco warehouses of Agrinio, which have become visual symbols of this inland city in western Greece, whose destiny has seen for some decades dependent on the price of tobacco on international markets. The study that follows describes the role played in the transformation of the town by the tobacco warehouses, the special buildings in which tobacco is processed and stored for export. Agrinio is considered here within a broad chronological and geographical context. Issues were examined such as influences from the rest of the world, and how they shaped the city's society and constructed space; how the treaty of Lausanne (1923) contributed to its economic growth by providing a la- 
bour force willing to work in the tobacco industry; how the building of these large warehouses influenced the city's urban development; and how the tobacco merchants' contact with Central Europe introduced fresh features that brought innovation to the city's architecture. The construction of the tobacco warehouses in Agrinio during the interwar years marked a period of financial prosperity for the city and shifted its attention outward. These buildings housed all stages in the processing, sorting and baling of tobacco leaves. They were deliberately built within the urban fabric, based on specific criteria that played a significant role in the town's urban development. The architectural form of these building complexes is interesting, reflecting at it does an amalgam of classicist, art deco, Vienna School and other influences. The transfer of technology from the architecture of Central Europe, besides contributing to the form of the warehouses, also extended to their typology and construction materials.

From the last quarter of the $19^{\text {th }}$ century to the period immediately after World War II, and above all in the 1920s and '30s, the cultivation and sale of tobacco was the primary economic activity in Agrinio, where the tobacco trade was closely associated in reciprocal relations with the society and the architecture of the region, as set out below (Rentetzi, 2008).

\section{The Role of Tobacco in the Growth of Greece's Economy and the Evolution of Its Cities}

The regions in which the so-called oriental tobacco ${ }^{1}$ was cultivated were eastern Macedonia and western Thrace (Kavala, Drama, Xanthi), the region around Smyrna, as well as Samsun and Bafra on the south coast of the Black Sea, where tobacco had been grown since the mid- $18^{\text {th }}$ century. From there, its cultivation spread to Greece, extending to the regions of Thessaly, Sterea Ellada (Central Greece) and the Peloponnese. Significant landmarks in tobacco production were the annexation of Thessaly into the Greek state (1881), and the liberation of Macedonia, parts of Thrace and the islands of the eastern Aegean, as an outcome of the Balkan Wars in 1912-1913. Another significant event was the influx of refugees after the Asia Minor disaster and the obligatory population exchange under the Treaty of Lausanne (1923), which brought in willing workers and ensured them employment (Flevaris \& Rentetzi, 2014).

Tobacco had been for decades one of Greece's main export products, together with cotton, culminating in the 1920s for tobacco and the 1930s for cotton. Greek foreign trade was reoriented and strengthened by these two agricultural products. Tobacco solved the problem of diminishing exports of raisins to saturated markets. It constituted a new source of foreign exchange and halted the dependence on exports to and the inflow of foreign exchange from the English market alone. The export model based solely on raisins was initially differentiated from, and ultimately replaced by that of tobacco. England was displaced as the primary destination for exports by Germany, which imported the largest quantities of tobacco. These two new products—-tobacco and cotton—also shifted the geography of agricultural development: to the northwestern Peloponnese with its raisins was added Crete (with its sultanas), Macedonia and Thrace (with tobacco and cotton), Agrinio and Argos (with tobacco) and the Serres plains, Thebes, Lamia and Thessaly (with cotton). The commercialization and monetization of farm produce were now extended to more regions, and hitherto unknown processes were set in motion to encourage regional development ${ }^{2}$.

Until the Balkan Wars in 1912-1913, tobacco production had been limited to Argolida, Fthiotida, Agrinio and Mesolongi. It satisfied mainly the domestic demand, as only a very small fraction of the crop was exported. The spread of tobacco farming in Greece was due to external rather than domestic factors such as the change of orientation or the modernization of crops. After the Balkan Wars, the annexation of Macedonia and Thrace, chiefly tobacco-producing regions, gave thrust to the processing of tobacco. In addition, the influx of refugees from Smyrna and the Pontos who specialized in tobacco farming, gave the trade an enormous boost. Tobacco yielded four times more income for farmers than any other product. This fact emerges from comparing the av-

\footnotetext{
${ }^{1}$ A significant contribution was made to our knowledge of tobacco by the recent international conference "Tobacco Roads: Technology Transfer in the Tobacco Industry during the Early Twentieth Century”, Kavala, Greece, 5-7 July 2013, Organizer Maria Rentetzi, Associate Professor, National Technical University of Athens, Athens Greece. Support team: Spyros Petrounakos, Georgia Markou, Spyridon Stelios, Dimitris Steriopioulos. Also related to the theme was the exhibition “Tobacco. 101 notes on oriental tobacco", Benaki Museum 11 June-31 August 2014. The exhibition highlighted oriental tobacco as a multi-dimensional commercial product by approaching it historically from various points of view. The exhibition was curated by architect Spyros Flevaris, who collaborated in its preparation with Maria Rentetzi as historical advisor. The exhibition was accompanied by the book Tobacco. 101 notes on oriental tobacco, Sp. Flevaris, M. Rentetzi, Benaki Museum, Athens 2014.

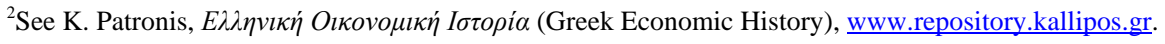


erage gross revenue from tobacco per hectare of land with that of total agricultural output in the decade between 1927 and 1936. In the interwar period, the impact of tobacco went beyond the bounds of agriculture. According to Th. Sakellaropoulos ${ }^{3}$, it influenced the economy, the society and the state as a whole. "It secured employment for broad rural and urban strata. It ensured the largest volume of incoming foreign exchange from exports. It was one of the most important sources of tax revenues in the state budget. Although tobacco occupied just 3\% $4 \%$ of the area cultivated, its share of the total income from farming amounted to approximately $15 \%$. Between 1927 and 1930 the value of the tobacco crop was even higher than average. It amounted to and even exceeded $20 \%$ of total farm produce. Some 150,000 families were employed in growing tobacco. Overall, tobacco gave employment to about $15 \%$ of the country's rural population. Most tobacco growers were small landowners who grew tobacco exclusively. The significance of tobacco, however, was even greater for the local economy, if one considers that it was the only crop in certain regions, such as Macedonia, Thrace, Agrinio etc. The favourable juncture for the product proved to be a source of wealth for this population."

On the contrary, the crisis of 1929 initially caused prices to fall in Greece, with repercussions that affected farm incomes and the country's balance of trade. Particularly marked was the decline in tobacco exports between 1931 and 1934, with its price dropping to about 1/3 of what it had been in 1929. The tobacco crisis led to a rapid reduction in people's standard of living, transforming tobacco-producing regions into hotbeds of demonstrations and social protest.

The influence of the tobacco trade on cities was great. Tobacco provided a channel of communication with central Europe. Through its significant economic activity, tobacco contributed to the development of the banking system. It was a source of wealth that also played a part in creating a new social model. Tobacco-related activity was likewise significant for the development of cities' urban fabric: the refugee settlements built in tobacco towns extended their residential area. The tobacco warehouses introduced architectural influences from central Europe: new typology, new styles and the use of reinforced concrete. The architecture of the tobacco merchants' homes, primarily in northern Greece, brought in the new trends that prevailed in European cities in the mid- $19^{\text {th }}$ century. The philanthropic work done by the tobacco merchants contributed to modernizing cities, the most characteristic example being Agrinio.

\section{The (Re)Creation of the Greek City, 1830-1940}

The early decades after Independence ${ }^{4}$ were characterized by the effort on the part of the Greek state to secure the country's urban development by rebuilding devastated towns and cities, creating new ones and giving priority to the network of settlements. Its goal was to ensure viable living conditions and to transform heaps of ruins and insignificant villages into cities capable of developing urban functions (Yerolympos, 1996; Bastea, 2000; Monioudi-Gavala, 2012b).

By recording state interventions to promote the urban reform of Old Greece ${ }^{5}$, the researcher acquires a picture of how urban planning policy ${ }^{6}$ was built from the ground up. The newly-constituted kingdom chose to set up new institutions staffed by new people, completely eliminating the conditions that had existed previously, thus eradicating features of the preceding foreign rule. The Eastern world was a thing of the past that had to be forgotten and replaced by the corresponding Western one. Models of European origin led to modernisation and progress, and the new national identity was based on the link with antiquity. The main instrument for achieving these goals was the city plan, urban development and everything related to the regulation of urban space. Towns were even renamed with this in mind (Vrachori became Agrinio ${ }^{7}$, Votsitsa became Aegio, etc.).

Widespread changes were afoot in the land. In the early decades of the $19^{\text {th }}$ century, there was no urban tradition in Old Greece. Settlements then should be described as "villages" rather than towns or cities, since their main features were an irregular road network and the lack of water supply and sewerage networks, which meant that water had to be drawn from cisterns and community wells. After independence, Greece followed European

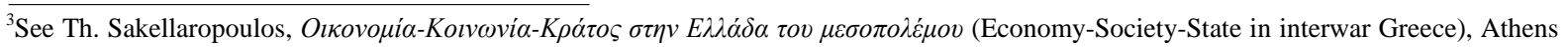
1991.

${ }^{4}$ Greece was established as an independent monarchy by the London protocol in 1830.

${ }^{5}$ Old Greece included the territories that were part of the first Greek State after the country’s independence from the Ottoman Empire.

${ }^{6}$ General State Archives, City Plan Archive, files 1 to 57.

${ }^{7}$ The city was called Vrachori (Imbrahoar) from the $16^{\text {th }}$ cent. until 1836, when it was renamed Agrinio. The sources speak of a small town under Ottoman rule which became the capital of the sanjak of Karleli between 1684 and 1699 after which it evolved into the military centre of western mainland Greece and a significant Turkish administrative centre.
} 
cultural models, and prepared itself to create regular, sanitary towns. In the vast majority of cases, planning gave priority to rational, sensible goals, rather than aesthetics. Straight streets with a constant width, squares dotted about the city, and public buildings on selected sites constituted major innovations. The plans had to show off the towns as hubs of a centralised, modern European monarchy, honouring their antiquities and meeting the needs of their inhabitants, thus symbolising the country's regeneration and its Western orientation.

The new urban planning and architecture aimed to change the society by creating a national identity and a sense of national pride. As Eleni Bastea writes: "The new buildings and new towns and cities of the $19^{\text {th }}$ century constituted the most unshakeable evidence of national progress. Indeed, they were oftentimes the only evidence of progress."

In addition to urban planning, significant changes were also made to the architecture of Old Greece. The traditional style was replaced by neoclassicism, which introduced new forms and construction techniques that were different from what builders had previously been using. Neoclassicism in Greece was linked with the visionary goal of national regeneration and the revival of the classical Greek architectural model. The new morphology brought in chiefly by $\mathrm{Otto}^{8}$ and the Bavarians became identified with the art of the ancient forefathers, after being welcomed enthusiastically by the society.

The features of urban development in Greece from the early $20^{\text {th }}$ century to World War II were radically different from those prevailing in central and western Europe. Around 1900, cities such as Athens, Patras, Volos, etc. had no problems related to the over-concentration of population and activities such as those faced by the large urban centres in industrially developed countries during the same period. The utilisation of space in Greek cities was, however, drastically affected by the influx of more than a million Greek-speaking refugees as a result of the Asia Minor disaster (1922). In January 1915, soon after the outbreak of World War I, Britain offered Greece significant territorial gains in Asia Minor, motivating it to enter the war as an ally of the Entente. This proposal led to successive events, including the Greek campaign in Asia Minor and the war against the Turks. It ended with the defeat of the Greeks, the tragedy of 1822 and the destruction of the Greek city of Smyrna. The treaty of Lausanne in 1923 regulated the obligatory population exchange between Greeks and Turks, and marked the uprooting of Greeks from Asia Minor (Llewellyn-Smith, 1998). According to the 1928 census, 1,221,849 refugees from Asia Minor came to Greece. Getting them settled was a major goal for Greek governments, which took a number of measures to provide them with both housing and employment. The settlement of the refugees took place in an organised way, on the initiative of the state, which implemented the principles of the modern movement in architecture.

\section{The Evolution of a Regional City in the Modern Greek State: The Case of Agrinio. Urban Planning, Demographic Features, the Economy}

Between the birth of the new Greek state and the interwar period, the town of Agrinio developed in a particularly interesting way, with some important special features (Monioudi-Gavala, 2010). It was among the regions of Greece to be declared independent in 1830 by the London protocol. Liberation from four centuries of Ottoman rule found the city devastated by the events of the War of Independence, and its population decimated. The rebuilding of Agrinio and all of Greece's other ruined towns was the primary concern of the newly constituted Greek state. Agrinio was chosen by the state to become the centre of a broader inland region, to have an urban plan and be subject to significant reforms. Both the cadastral survey of 1843-1845 and the approved plan of 1852-1853 bear witness to the state's determined effort to put the city on track toward growth and modernisation.

Following the War of Independence, Agrinio was a wasteland, in which the prevailing image was of large heaps of stone that had piled up from the destruction of pre-revolutionary Muslim buildings. The road network that branched out from the town centre was built on streets with irregular dimensions and usually narrow in width. Roads crossed neighbourhoods and went beyond, linking the city with its agricultural hinterlands and other regional centres.

The town plan implemented during the reign of Otto attempted to rearrange the previously existing urban planning outline. Agrinio may have been in ruins, but it was still alive, although in urgent need of reconstruction and planning that took into account the earlier building lines. The existing street plan was retained in the new town, but with different geometric features. The centre was moved to a site southwest of the old one, to the

${ }^{8}$ Otto (1 June 1815-26 July 1867), was a Bavarian prince and first king of the Kingdom of Greece. 
town's new, rectangular main square. Around the square, uniform narrow-fronted lots were created, as required by the town planning precepts of the period. The new Agrinio town plan was characterised by the concepts of organisation and order. It aimed to improve the road network by straightening old roads and building new ones, without upsetting the existing fabric of the traditional old town. Thus, straight roads with a constant width replaced the narrow, labyrinthine streets from the period of Turkish rule in approximately the same location, thus ensuring public thoroughfares for the smooth flow of traffic heading out of the town.

In the final decades of the $19^{\text {th }}$ century, a network of urban functions was created in Agrinio. The approved plan of 1852-1853 began to be implemented there. In addition to the new road network and public squares, the urban and industrial growth that characterized Greece under the governments of Kharilaos Trikoupis was also visible in Agrinio. Major infrastructure works (railway connection, road network) made possible the emergence of a manufacturing sector and expansion of the export trade. The developmental impetus continued and became much more marked in the early decades of the $20^{\text {th }}$ century.

The main demographic features of Agrinio in the early decades after 1830 were the gradual settlement and population renewal brought about by the high percentage of newcomers from Souli and other parts of Epirus. The resettlement process continued for many decades, due to internal migration from the mountainous hinterlands and other regions. The new local community was incorporated into the national society and its economy through the thrust provided by its various newcomers. Refugees from the parts of western Greece still under Turkish occupation, peasants from the hinterlands and other inhabitants of Greece, the former inhabitants now repatriated, the once-wealthy families of the armatoli (Christian militia forces), the families of the fighters and captains of the revolution and others, all regarded Agrinio, with its fertile plain, as a good place to settle. The fading of its earlier, multicultural identity — that had been shaped by a mixed population of Muslims, Christians and Jews in the pre-revolutionary town and was lost during the War of Independence-facilitated the development of a new, shared local identity ${ }^{9}$. Along general lines, the town relied for its existence on a limited agricultural output, a socially and culturally heterogeneous population and a marked dependence on the central authority. Later, during the last decades of the $19^{\text {th }}$ century, its economic and social progress was based on the cultivation, processing and sale of tobacco.

By the end of the $19^{\text {th }}$ century, new population movements had increased the number of its inhabitants to 7000 . A large population increase was observed with the sudden influx of refugees from Asia Minor and the Pontus after the disaster of 1922 and the agreement between Greece and Turkey on population exchange under the Treaty of Lausanne in 1923. The refugees represented a 43.57\% increase in the population of Agrinio (12,757 inhabitants in 1920,18,339 in 1928) and revitalised it, leading to a financial boom mainly by supplying willing workers to process tobacco for commercial purposes. A large percentage of these refugees, both men and women, worked in the tobacco warehouses. The tobacco merchants' private initiative of building and operating the large tobacco warehouses provided job opportunities, while the willing hands of the middle-class refugees, in turn, contributed to the rapid growth of the tobacco trade. The main goal of the state was to assimilate the refugees, help them acquire a trade and make property accessible to them. The building of the refugee settlements northwest of the city was the key to this venture, as it created the model that linked labour and property ownership with security, and prevented the social unrest that might have been caused by the economic crisis of the period. The refugee district of Agrinio had little in common with the cosmopolitan cities of Asia Minor in which these refugees had previously lived. Its landscape reflected the image of a middle and working class suburb. In any event, the provision of housing was not a gift from the Greek state to the refugees, but a policy that created significant and clearly defined financial obligations, which became the foremost cause of friction between the refugees and Greek governments, while the issue of refugee debts was a serious concern in political life during the interwar years (Monioudi-Gavala, 2012a).

In the early decades after the town's rebirth, the citizens lived in a closed economy with a low index of cash in circulation; its main features were local production for local consumption. In the last quarter of the 19th century, however, changes began to be observed; the advent of the railway meant that Agrinio was no longer cut off from the rest of the country, thus fostering trade to inland regions. Tobacco was cultivated intensively in the provinces surrounding the Agrinio region during the last quarter of the $19^{\text {th }}$ century, placing them, in 1875 , among the regions of Greece with a significant output (Anastasopoulos, 1947). The increased production of tobacco led to its trade, and favourable international publicity was generated when the Municipality of Agrinio received an award for the excellent quality of its tobacco at the World's Fair in Paris in 1878.

\footnotetext{
${ }^{9}$ See Bada, K. “Agrinio”, www.culture.upatras.gr, (accessed 5 July 2013).
} 
The tobacco crop expanded in particular between 1900 and 1930 owing to increased domestic demand, but above all to demand from the international market. In Agrinio in 1920 there were 22 firms in the export trade, many of which were agents of foreign companies and monopolies (Bada, 2003).

Beginning in the early $20^{\text {th }}$ century, Agrinio evolved into a commercial hub and then into a significant centre for the production, trade and export of tobacco, which was promoted by the inhabitants of the city and its surrounding villages in response to growing demand. Tobacco became virtually the sole crop in the region, replacing earlier produce that reflected the agrarian-stock-breeding life of the plain. The expansion of the tobacco crop in the region was also encouraged by a coincidence that favoured Greek farmers: the agrarian reform implemented in 1911. In addition, the spread of the cooperative movement throughout the entire Greek countryside liberated agricultural output from the hurdles and limitations that had existed previously. Through agrarian reform and the distribution of the land, the great majority of farmers became small owners and producers. Also in the second decade of the $20^{\text {th }}$ century, due to the proliferation of agricultural cooperatives in the countryside surrounding Agrinio, cheap loans were made available for the expansion and adjustment of crops and reduced the usury that had become the scourge of farmers throughout the $19^{\text {th }}$ century. Thus, in the period between 1900 and 1930, the increase in the global consumption of tobacco (the popularity of smoking among the upper income classes filtered down to the middle and lower classes), together with the financial conditions favourable to agricultural produce, gave an enormous thrust to the growing and processing of tobacco in the broader Agrinio region.

Historical and economic conditions sometimes created financial growth for the city and its inhabitants that was entirely related to the demand for tobacco; at others, some economic crisis (such as the crash of 1929) had negative repercussions on the city's labour force, its trade, its light industry and its tobacco producers. In the 1930s and the early post-war period as well, Greek tobacco, the main commodity produced in the region, was successively affected by the rise, fall and reconstruction of the German economy between 1930 and 1955. Tobacco was the main Greek product sold to Germany and the most significant source of funding for the rearming of Greece by the German armaments industry in the 1930s. In the interwar period, Germany was a privileged partner in Greek tobacco production. Through the clearing signed in 1932 between the Bank of Greece and the Reichsbank, Germany was the primary purchaser of Greek agricultural products in exchange for re-arming the country.

The tobacco trade, and indeed all agricultural production, sustained enormous losses in World War II and the Civil War that followed. In the early postwar period (1946-1954), Greek efforts to have its tobacco surpluses absorbed were focused on the German market (Patronis \& Angeli, 2010).

In Agrinio, there was a labour movement of tobacco producers and tobacco workers. The Union of Tobacco Workers was established there in 1911. It played a leading role in establishing the Agrinio Labour Centre in 1918 and constituted the main body of the city's labour movement for the next three decades. The building of the large tobacco warehouses and the arrival of the refugees swelled the ranks of the tobacco workers, men and women alike, to more than 2000. Struggles of a mass and militant nature were fought for higher wages by the labour movement, with strikes and dynamic protests that ended in bloodshed and casualties. In the early 1930s, the Metaxas dictatorship was imposed and soon after, World War II broke out.

In the decades after the war, the old families involved in the processing and trade of tobacco, who were also financial and social leaders, gradually transferred their activities and investments to Athens (Papastratos, Iliou, Keranis, Karelias, etc.). As a consequence of the industry's re-location to Athens and other urban centres, many of Agrinio's inhabitants-workers, craftsmen and tradesmen-made a similar move. Afterwards, the city evolved into an agrarian-urban centre closely associated with its surrounding farms, where tobacco continued to be grown. Today, however, tobacco production, with which the fate of the town had been linked for many decades, has ceased altogether.

\section{The Tobacco Warehouses of the Interwar Period and Their Role in the Development of Agrinio and Its Urban Architecture}

The geographical location of Agrinio favoured the development of commerce, and its fertile lands ensured a steady output of products to supply foreign trade. The expansion of the tobacco crop and trade changed the nature of the town. Starting in the early $20^{\text {th }}$ century, it transformed Agrinio into a dynamic financial centre and brought it into contact with the rest of the world. The main factor in the city's evolution was the accumulation of 
wealth from the tobacco trade. During the interwar years, the old town was transformed into a modern city; a primary factor in this change was the construction of the tobacco warehouses.

The large-scale production and export of tobacco fostered the development of the manufacturing sector: the tobacco warehouses were built for the processing, sorting and baling of tobacco. But there were no factories for cutting tobacco, making cigarettes and cigars, or producing goods in which to roll tobacco.

Before the warehouses were erected, tobacco was stored either in small single-storey buildings scattered around the city or on the ground floor and in the basement of merchants' houses. The construction of these large warehouses in the interwar period was a significant phenomenon in the city and signalled both its financial prosperity and its new outward-looking orientation. The most significant of these buildings, in terms of their architecture and size, were those of the Papastratos Brothers, the Papapetros Brothers, Iliou-Generale and Kamposioras, together with the now demolished buildings of the Panagopoulos Brothers and Kokkalis. A tobacco warehouse was also built between 1924 and 1930 by the National Bank of Greece as an annex to its Agrinio branch $^{10}$. Most of these buildings were situated near the railway station and had easy road access to the agrarian hinterlands, the two main factors determining their location. The fact that the large majority of tobacco workers ${ }^{11}$ lived in refugee camps on the opposite side of town did not influence the site of their workplace or vice versa. These refugee settlements were built northwest of the city. The main criterion for their location was the availability of land on which to build them, together with the need for them to be a self-sufficient part of the existing city (Monioudi-Gavala, 2012a).

Construction of the tobacco warehouses had a significant effect on the urban development of Agrinio (Figure 1). That they were built on the south side directed the city's expansion southward and eastward, through a revision of the 1929 plan. The urban reform itself was directly linked to tobacco, as its purpose was to regulate the city's growth at the peak of the financial prosperity generated by tobacco. The 1929 plan was financed generously by the Papastratos brothers who owed their prosperity to tobacco. It regulated the city's extensions. It organised planning for the new districts to the north, west and south of the city. Without it, these extensions would have been built in a haphazard way, without the regularity and order desired by the Greek state. The tobacco warehouses likewise contributed indirectly to the city's new look. The wealth accrued from the tobacco trade allowed some members of the upper class to undertake philanthropic projects. In this regard, the Papastratos brothers in particular endowed the city with significant public benefit works including: the Papastrateia Schools, the design of which was awarded to the distinguished architect Georgios Panzaris; the parkland of about 54 stremmas ( 1 stremma $=1 / 4$ acre or $1 / 10$ of a hectare) which they purchased and landscaped as an oasis of greenery and leisure and then donated to the municipality; and infrastructure works such as electric lighting. First a power plant was built and then the grid in 1928, also a Papastratos project. These philanthropic works changed life in Agrinio.

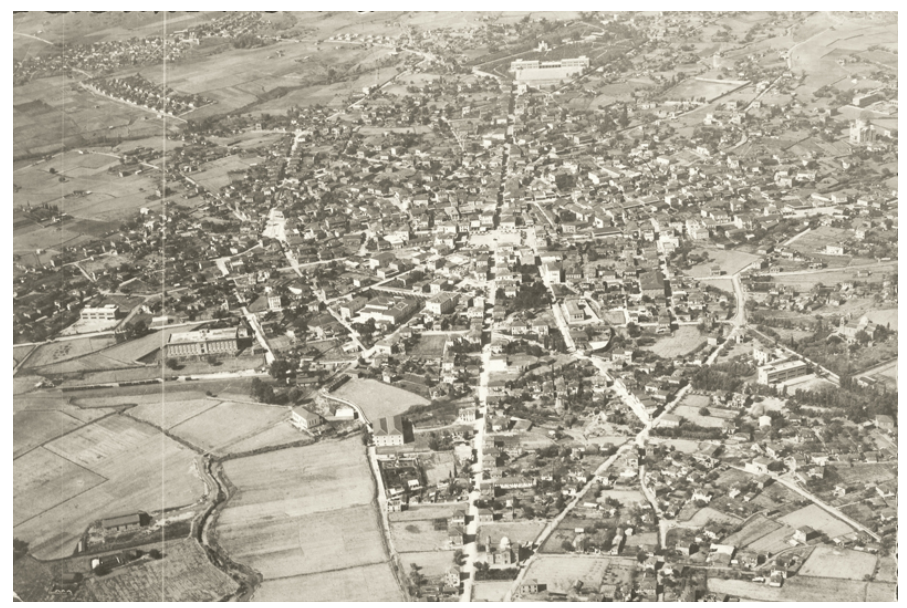

Figure 1. Example Interwar aerial photograph of Agrinio. The tobacco warehouse buildings can be distinguished by their volume. Xythalis Photography Archive. Source: Monioudi-Gavala (2010).

\footnotetext{
${ }^{10}$ Historical archives of the National Bank of Greece. The building was demolished and replaced by the new branch.

${ }^{11}$ Most of them were in fact refugees from Asia Minor who had arrived between 1920-1928.
} 


\section{Architectural Recognition: The Transfer of Technology and the Diffusion of European Models}

The period from 1900 to 1940 witnessed revolutionary changes in European architecture. The new realities and needs of the industrial society led architects to devise solutions to the great problems of the era. They resolved issues of form by studying a building's function and structure. The foundations were laid for modern architecture by the pioneering work of architects from the Vienna School, the Chicago School and the Deutscher Werkbund, and of avant-garde architects such as Frank Lloyd Wright, Auguste Perret, Adolf Loos, and others. Modern architecture was consolidated after World War I by the Bauhaus and the work of Walter Gropius, Mies van der Rohe, Le Corbusier and others. But the modern movement could not suppress more conventional and academic architectural trends. Great variety can be seen in the architecture of industrial buildings constructed in Greece between the late $19^{\text {th }}$ century and the interwar years, as it was directly related to the site on which the factory was built. When a category of buildings, such as factories, first appeared in a community, the early efforts to arrive at new forms were usually based on borrowings from other types of buildings from the past. And in most cases, the echo of neoclassical principles was implemented: magnificence, volume in composition, symmetry and order. However, during the interwar period, modern European trends found fertile soil in Greece (Fessas-Emmanouil \& Marmaras, 2005). Most Greek architects had studied architecture at schools in Europe or Istanbul, since the Faculty of Architecture at the National Technical University in Athens was not established until 1917. They learned about contemporary currents — art nouveau, jugendstill, art deco, etc.—and had lived in Europe's architectural capitals. In 1933, at the Fourth CIAM, these architects presented recent Greek works of the modern movement to their visiting colleagues, who were impressed. The architecture of Greece's industrial buildings in particular followed the principles of the modern movement, with their spare lines, flat roofs and the provision of natural lighting. A significant role was played by German and Austrian architecture in shaping new design concepts in Greece after World War I. Principles, building solutions and morphological themes drawn from the international, mainly Central European, modern movement were used to design functional, standardised buildings such as schools, hospitals, and factories. More conservative solutions were also used, on which the morphology followed simplified neoclassical models. From the interwar period on, the use of reinforced concrete and the Greek businessman's new attitude toward the European image of his company introduced the building solutions and forms of the modern movement (Demiri, 1991).

The city of Agrinio followed developments by changing the traditional or neoclassical morphology to modernism and instead of non-specialized buildings constructed industrial ones for storing tobacco, which embodied strong influences from Central Europe. The morphology and layout of the two-storey tobacco merchants' homes - on the ground floor and in the basement of which tobacco bales were initially stored-followed either the traditional architecture of the region or a simplified late neoclassical style. The ground floors, independent tobacco warehouses, were built of stone masonry, with ceramic tile roofs and a loft. They were not part of any particular building programme, just ordinary storage areas. The heyday of the tobacco trade in Agrinio and the financial prosperity that followed in the interwar period made it possible for new types of buildings and new styles to appear, owing to the contribution of architects and engineers. The now demolished Panagopoulos warehouses, for example, were designed by the distinguished architect Vassilios Kouremenos. At the same time, his collaboration with the Panagopoulos brothers brought him in touch with the municipal government ${ }^{12}$, after which the City assigned him to design the city market, the municipal slaughterhouses ${ }^{13}$ and the water reservoir, further enriching Agrinio with remarkable buildings. The Papastratos Brothers commissioned another distinguished architect, Georgios Panzaris to design the Papastrateia School buildings. Regarding morphology, eclecticist buildings with classicist allusions co-existed with those exhibiting a more contemporary approach, influenced by the modern movement. This architectural multiformity was a result of the differing choices by the middle class of the period.

The interwar period in particular was one of major reorientations in architecture, with models from Central Europe and elsewhere. During the heyday of the tobacco industry, houses of a new type were built, with a variety of features borrowed from European models, and with different architectural forms from the earlier ones that had followed the local tradition or showed classicist influences. One typical home is an interesting example of art nouveau in Agrinio ${ }^{14}$.

\footnotetext{
${ }^{12}$ Minutes of city council meetings in 1929 and 1930.

${ }^{13}$ The municipal market is currently being repaired. The slaughterhouses have been demolished.

${ }^{14}$ At 17 Papastratou St.
} 
The tobacco warehouses played a significant role in the history of the city's architecture and, owing to their sheer size, even in relation to the present-day scale of buildings, still constitute imposing landmarks. With their large surface and three or four storeys, they played a decisive role in the creating the image of Agrinio.

The tobacco warehouses brought innovations to the city's architecture, especially the use of reinforced concrete, which may have been introduced as construction material in urban housing as a result of the early works on the Papapetros tobacco warehouse in 1923 (Figure 2). The architectural forms applied to these industrial buildings also influenced residential architecture.

The tobacco merchants of Agrinio cared about their buildings, as testified by Sotiris Papastratos ${ }^{15}$ in his report on 1936: "Our Company realised in time that the warehouses in which tobacco from various places was processed were unhealthy for the workers... But also that the tobacco needed much more careful handling. At a time when not one of us four brothers had a house of our own, our Company drew up a construction programme and successively built twelve exemplary large tobacco warehouses in the largest tobacco-producing centres" (Papastratos, 2012). The appearance of these warehouses shows that the companies had allocated significant funds to achieve a high level of aesthetics and construction. The buildings served to publicise the companies, both in the local community and among their business associates. The significance that the Agrinio tobacco merchants attached to their buildings is also revealed by the choice of the professionals to whom they entrusted their design, who were either architects or engineers with special skills in architectural design. The Papastratos and Kamposioras warehouses were works by the architect Vassilios Tsouloufis ${ }^{16}$ who worked in Agrinio. The later Kokkalis building (now demolished) was undertaken by civil engineer K. Kazantzis, also from Agrinio, who had studied in Germany. The Panagopoulos warehouse (now demolished) was by Vassilios Kouremenos ${ }^{17}$, a highly reputed architect, professor at the National Technical University School of Architecture and Academician. The selection of this distinguished architect proves the owners' desire for a prestige building.

The tobacco warehouses are conspicuous, built on large lots along the major thoroughfares and easily accessible from the railway station and the rural interior. Through them a new type of building was introduced into the city, providing models for other structures of similar size and importance. These building complexes have an interesting architectural form, revealing a variety of influences. Those of Papastratos, Kamposioras and Iliou-Generale are characterised by classicist influences in the three-part structure of their volumes with base, trunk and crown, and the symmetrical treatment of their façades. The decoration on all the other external features of these industrial buildings likewise shows classicist influences.

The demolished Panagopoulos warehouse was special in that it expressed the eclecticist convictions of Vassilios Kouremenos. It showed classicist influences (on the tripartite structure and the symmetrical treatment of the façades), but also "Greekness", as rendered by the glazed ceramic tiles bearing coloured representations of $\mathrm{Ni}$ cotiana (tobacco) plants and blossoms. The desired "return to tradition" was achieved primarily through the decoration and colour.

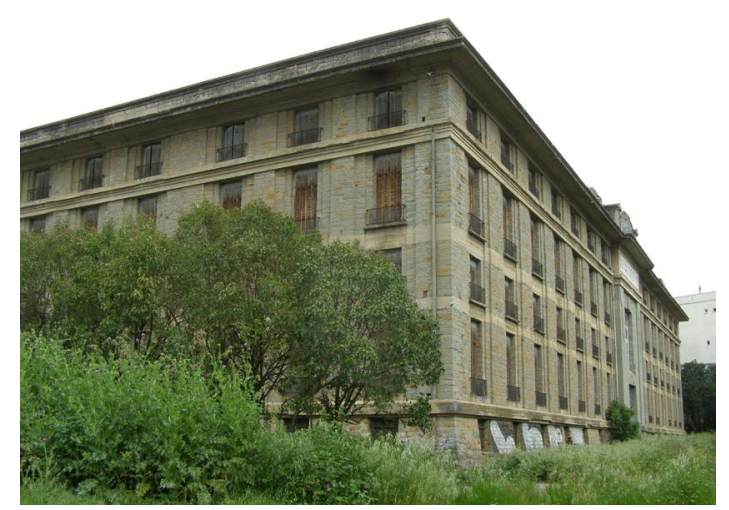

Figure 2. Papapetros Brothers tobacco warehouse.

\footnotetext{
${ }^{15}$ The Papastratos company facilities were among the best of Greece's various tobacco centres.

${ }^{16}$ The architect Vassilios Tsouloufris or Tsouloufis (1850-1927) worked in construction in Odessa and Constantinople, where he studied architecture at the School of Fine Arts.

${ }^{17}$ Kouremenos belonged to the category of Greek architects of the interwar period who distinguished themselves by their insistence on the eclectical style throughout their professional careers.
} 
Of particular interest as regards its architectural form is the Papapetros warehouse. It was built with a loadbearing structure of reinforced concrete, in conjunction with visible stone masonry, using the hewn gray rock of the Agrinio region, a feature of the local tradition. It is a monolithic building that combines its imposing weight and volume with an interesting form. The entrances on the two long sides are differentiated architecturally by doorframes of sculpted art deco stonework (Figure 3). The concrete ceilings feature perimetric protrusions in the form of a decorative frieze with mouldings. The flat concrete roof also has a perimetric protrusion in the form of a cornice. The building expressed the new, more European image that the company's premises were intended to project, and is strongly reminiscent of buildings in Central Europe.

Professor Nikolaos Cholevas ${ }^{18}$ regarded this building as having been influenced by the late works of the Vienna School and especially those of Otto Wagner (Andrikopoulos, 2010). Prevalent on it were the horizontal line, level roof and plain, fundamental features of modern architecture from the interwar period on. Its style is reminiscent of the design principles of Peter Behrens, the architect who endeavoured through his works to demonstrate that function and technical requirements do not necessarily determine form, but on the contrary, that the architectural elaboration of form can contribute to the cultural assimilation of a productive new reality (Anderson, 1977). The name of the building's architect is not known, but the family's descendants have retained the information that he was German.

The transfer of technology from the architecture of Central Europe to the tobacco warehouses of Agrinio was not exhausted in the form of the Papapetros warehouse. It also extended to another two levels: the typology of the buildings and their construction materials.

The typology of the buildings is absolutely integrated into the principles of functionalism. The Papapetros warehouse is characterised by the symmetry of its floor plan. In the centre is an area seven metres wide lighted through a transparent roof. The building's stairways are located in this central space, as is the winch for moving bales of tobacco. Similar sections are laid out on either side of this space, and contain four rooms, two on each side, that communicate through internal doors. In the middle of each room there are twelve supporting struts with the same cross-section.

Even more impressive was Kouremenos's introduction of modernist ideas into the treatment of the floor plan on the Panagopoulos warehouse, which is characterised by rational design using a grid, a primary element in modern architecture. Although the building demonstrates conservative choices of form, its typology was modern, and thus it combines modernism in its typology with the national identity in its architectural form.

Construction materials were also imported from Central Europe to some degree, and used to construct interwar buildings as well as to expand them in the postwar decades. In the National Bank of Greece Archives, an agreement has been preserved, signed in 1958, not long after the war, by the Panagopoulos brothers with the firm Bergbau-Handel of Berlin ${ }^{19}$, to supply vacuum glass bricks for the enlargement of their building.

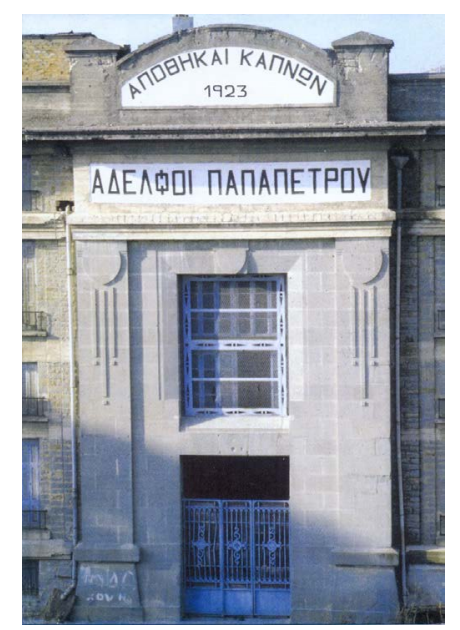

\section{Figure 3. Papapetros Brothers tobacco warehouse.}

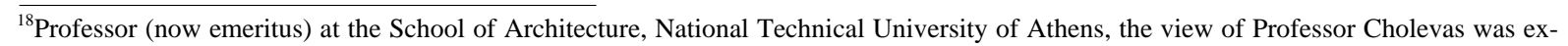
pressed in Andrikopoulos' doctoral thesis.

${ }^{19}$ Historical archives of the National Bank of Greece.
} 
The transfer of technology to architecture is a direct outcome of the tobacco merchants' dealings in Central Europe. In 1920, the Papastratos brothers established a branch in Amsterdam and then in Dresden and Berlin. In Dresden, they did business with the factory of G.A. Yasmatzis (Papastratos, 2012: pp. 176-177). Imported technology was used on their company's factory in Piraeus, the preliminary drawings for which were done in Greece, but the final design was completed in Germany (Papastratos, 2012: pp. 189-190). In addition, the clearing signed in 1932 between the Bank of Greece and the Reichsbank brought the tobacco merchants into continuous contact with Germany for many years.

The tobacco warehouses of the interwar period in Agrinio contained:

-Areas for storing the bales purchased from tobacco producers.

-Humidifying areas, where the tobacco was humidified, then sorted.

-Large areas (salons), in which the leaves were graded for quality and processed.

-Areas in which specialised staff put together the "blend", a mixture of tobacco leaves from different regions, of different varieties etc.

-Areas for commercial packing.

-Areas for storing commercial packages.

-Administration and office areas.

The areas for processing the tobacco (salons) were on the top floor, open spaces with large windows, well lighted for easier processing. The storage areas, also open, were on the lowest level, with the same dimensions but smaller openings, since preservation requires special conditions. The processing areas had higher ceilings, with lower ones in the storage areas. There were no sanitary facilities inside the buildings.

The Papastratos Brothers' warehouse had an independent administration and office space and residence-guest house in a separate building. In the others, administration and office space was housed in the same building: in the Kamposioras and Kokkalis warehouses the residence and offices were accommodated on the top floor of the building (with a private entrance for the residence); in the Iliou-Generale warehouse the office space was located on the elevated ground floor.

The tobacco warehouses in Agrinio influenced industrial architecture throughout Greece. They were among the first buildings designed and constructed specifically to serve the needs of the tobacco trade. Strong architectural influences from Central Europe, with which the tobacco merchants of Agrinio traded in the early decades of the $20^{\text {th }}$ century, soon reached Agrinio, and went from there to the other regions in which Agrinio tobacco merchants were active, such as Athens and Piraeus (Keranis, Papastratos, etc.). The early use of reinforced concrete and the functional organization of the ground plans for the tobacco warehouses in Agrinio (Papapetros, Panagopoulos) were among the first indications of the growth and modernization of Greek industry in the 1920s and 30s and the early postwar decades.

\section{Afterword}

The tobacco warehouses of Agrinio have become visual symbols of this inland Greek city, whose destiny has seen for decades integrally linked with the tobacco trade. The study described the role played in the town's transformation by the construction in the interwar years of the large warehouses that housed all stages in the processing, sorting, baling and storage of tobacco leaves.

They marked a period of financial prosperity in Agrinio and shifted its attention outward. They likewise shaped the city's society and constructed space and influenced its urban development. The architectural form of these building complexes reflects an amalgam of classicist, art deco, Vienna School and other influences. The influence of Central European architecture also extended to their typology and construction materials.

Throughout this period, from the establishment of the Greek state to recent years, relations between Greece and European countries have been strong and welcome. In urban planning and architecture, the influences from Central Europe were very important. Both the model of urban transformation implemented in Greek cities, and the neo-classical style that prevailed in architecture came to Greece in the $19^{\text {th }}$ century, primarily with King Otto and the Bavarians. Later, during the interwar period, modernism in architecture also arrived from Central and Western Europe. On the local level in Agrinio, the international tobacco trade and the large tobacco warehouses built between the world wars to house it were an expression of Greece's relations with the West.

\section{References}

Anastasopoulos, G. (1947). The History of Greek Industry 1840-1940 (in Greek). Athens: Greek Publishing Company. 
Anderson, S. (1977). Modern Architecture and Industry: Peter Behrens and the Cultural Policy of Historical Determinism. Oppositions, 11, 53-71.

Andrikopoulos, E. (2010). The Architecture and Urban Planning of the Interwar Period in the City of Agrinio (in Greek). Athens: Technical Chamber of Greece.

Bada, K. (2003). Conference Proceedings: The Memory of a Provincial Urban Town and Landscape. Agrinio up to the 1960s. Athens: Metaihmio \& Municipality of Agrinio.

Bastea, E. (2000). The Creation of Modern Athens, Planning the Myth. Cambridge: Cambridge University Press.

Demiri, K. (ed.) (1991). Industrial Buildings. History, Rehabilitation, Design. Architecture in Greece, 25, 55-108.

Flevaris, Sp., \& Rentetzi, M. (2014). Tobacco. 101 Notes on Oriental Tobacco. Athens: Benaki Museum.

Llewellyn-Smith, M. (1998). Ionian Vision. Greece and Asia Minor 1919-1922. London: C. Hurst \& Co. Publishers Ltd.

Monioudi-Gavala, D. (2010). Agrinio. Urban Development from Regeneration to the Heyday of the Interwar Period [18301940] (in Greek). Agrinio: Municipality of Agrinio.

Monioudi-Gavala, D. (2012a). Urban Transformation of Agrinio during the Settlement of the Refugees, 1922-1930 (in Greek). International Conference on the Local History and Culture of Trichonia and Nafpaktia, Vlohos, Thermo, Nafpaktos, 9-11 June 2012, 1-12. www.livemedia.gr/video/25479

Monioudi-Gavala, D. (2012b). Urban Planning in the Greek State 1833-1890. Agrinio: Department of Cultural Heritage Management and New Technologies, University of Western Greece.

Papastratos, E. (2012). Effort and Its Reward (in Greek) (2nd ed.). Athens: Gema.

Patronis, V., \& Angeli, M. (2010). Not One Leaf of Tobacco: Agrinio Tobacco in the Turbulent Decade of the 1940s (in Greek). In K. Bada, \& Th. Sfikas (Eds.), Occupation-Resistance-Civil War. Etoloakarnania between 1940-1950 (pp. 137156). Athens: Paraskinio.

Rentetzi, M. (2008). Configuring Identities through Industrial Architecture and Urban Planning: Greek Tobacco Warehouses in the Late Nineteenth and Early Twentieth Century. Science Studies (Special Volume) Simon Guy \& Albena Yaneva (Eds.), Understanding Architecture, Accounting Society, 21, 64-81.

Fessas-Emmanouil, H., \& Marmaras, E. (2005). 12 Greek Architects of the Interwar Period. Heraklion: Crete University Press.

Yerolympos, A. (1996). Urban Transformations in the Balkans (1820-1920). Thessaloniki: University Studio Press. 